\title{
JOURNAL.RU
}

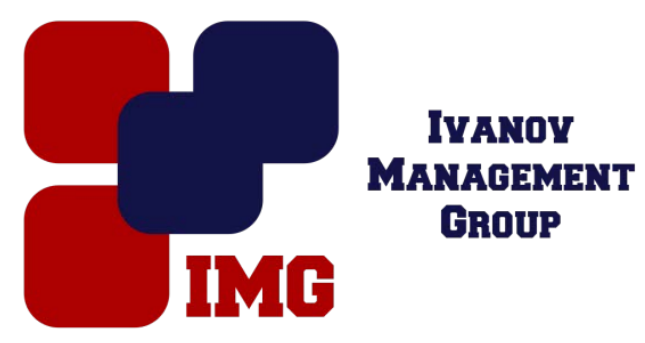

Кошкина И.В., Кардашина Е. С. Саратовский национальный исследовательский государственный университет имени Н.Г. Чернышевского Саратов, Россия

doi: 10.18411/lj-31-03-2017-1-10

idsp 000001:lj-31-03-2017-1-10

\section{Воспитание единственного ребёнка: сфера интересов и уровень развития коммуникативных способностей}

\section{Аннотация}

Статья посвящена исследованию развития коммуникативных способностей школьников, которые являются единственными детьми в семье. Рассмотрены актуальные сферы интересов младших школьников.

Ключевые слова: единственный ребёнок, сиблинги, коммуникативные способности, сфера интересов, младший школьник.

\section{Abstract}

Article is devoted to a research of development of communicative capabilities of the schoolchildren who are the only children in a family. The area of interests of junior schoolchildren has been considered.

Keywords: only child, siblings, communicative abilities, area of interest, junior schoolchild.

В последнее десятилетие в России всё больше растёт доля семей с одним ребенком (по данным 2010 года она составила 65,5\%) [1]. Так в чем же причина такой статистики? Почему в нашем обществе продолжает расти процент семей, с единственным ребёнком?

Опросы показывают, что одни родители ссылаются на нехватку времени изза современного ритма жизни, другие - на нехватку средств, а третьи считают, что единственный ребенок не будет нуждаться ни в чем, будет лучше развиваться, и не лишен их внимания. Однако последнее имеет два возможных исхода развития ребенка: либо он останется зависимым и беспомощным малышом из-за гиперопеки родителей, либо, приложив все силы, станет компетентным и состоятельным взрослым. Однако для второго исхода не только ребенку, но и родителям приходится прикладывать немало усилий.

Единственные дети - это дети, которые не имеют братьев и/или сестёр и одни воспитываются родителями [5]. Как правило, единственные дети, отличаются наличием высокой самооценки, эмоции более устойчивы, поскольку 
он не испытывает волнения по поводу соперничества с сиблингами [3]. Наряду с первенцами, они имеют самый высокий IQ и самый высокий показатель потребности в достижении результатов [2].

Как известно, первоначальные коммуникативные навыки ребёнок получает в семье от родителей или более старшего поколения в лице бабушек и дедушек. Однако для полноценной социализации детям необходимы сверстники. Ведь такие черты как поддержка, взаимопомощь, сдержанность, навыки общественного поведения гораздо легче формируются в непосредственном общении. Формирование коммуникативных навыков детей с сиблингами происходит раньше и проще, чем у единственных детей, так как начинается еще в семье.

Многочисленные исследования показывают, что единственные дети испытывают сложности с установлением межличностных контактов конфликтуют в учебных и рабочих коллективах, испытывают большие трудности в супружеских отношениях, поскольку не умеют уступать, тяготеют к одинокому образу жизни. Они склонны к эгоизму и имеют самую низкую потребность в социальном взаимодействии, стремятся сохранять максимальную независимость [2].

В связи с этим развитие коммуникативных способностей у единственных детей приобретает особую значимость в их обучении и воспитании.

Мы провели исследование по определению уровня развития коммуникативных способностей и интересов младших школьников. С целью определения взаимозависимости: есть ли разница в исследуемых явлениях у детей, являющихся единственным ребенком, и у детей, воспитывающихся в семье с другими детьми. В эксперименте приняли участие 23 обучающихся 2 «А» класса МОУ «СОШ №6» г. Саратова, 10 из которых являются единственным ребенком в семье.

Для выявления уровня развития коммуникативных способностей у детей использовалась модифицированная методика Цукерман Г.А. «Кто прав?». Детям предлагалось прочитать тексты трех маленьких рассказов и ответить на поставленные вопросы [4].

После обработки данных, были выявлены следующие результаты (см. табл. 1):

Таблииа 1

Уровень развития коммуникативных способностей

\begin{tabular}{|c|c|c|c|}
\hline \multirow{2}{*}{ Кол-во детей в семье } & \multicolumn{3}{|c|}{ Уровень } \\
\cline { 2 - 4 } & $\begin{array}{c}\text { Низкий } \\
\text { уровень }\end{array}$ & Средний уровень & Высокий уровень \\
\hline Единственные дети & $60 \%$ & $20 \%$ & $20 \%$ \\
\hline Дети с сиблингами & $70 \%$ & $15 \%$ & $15 \%$ \\
\hline
\end{tabular}

«Высокий» уровень развития коммуникативных способностей имеют $20 \%$ детей, которые являются единственными в семье и $15 \%$ детей, которые имеют братьев или сестёр. Дети учитывали разные позиции персонажей и смогли высказать и обосновать свое собственное мнение. Такой же процент детей $(20 \%$ и $15 \%$ соответственно) продемонстрировал «средний» уровень. Учащиеся допускали существование разных точек зрения, что разные мнения по-своему справедливы либо ошибочны, но не всегда могли обосновать свои ответы.

$60 \%$ единственных детей и $70 \%$ детей, имеющих сиблингов, имеют «низкий» уровень развития коммуникативных способностей. Анкетируемые 
принимали сторону одного из персонажей, считая вторую позицию однозначно неправильной. Однако, следует учитывать и тот факт, что высокий процент «низкого» уровня связан с возрастом анкетируемых.

Отдельного рассмотрения заслуживают анкеты единственных детей с «низким» уровнем. 30 \% опрошенных не смогли дать ответ на все поставленные вопросы или прокомментировать тот или иной выбор.

На основании этих данных, можно сделать вывод, что в данном возрасте, дети, являющиеся единственными, имеют уровень развития коммуникативных способностей несколько выше, чем дети, воспитываемые с братьями или сёстрами. Однако, дети не единственные в семье, отстаивая свою точку зрения, чаще аргументируют свой выбор и приводят конкретные доводы.

Для диагностики интересов младших школьников, нами использовался опросник «Карта интересов» [6]. Обучающиеся отвечали на 35 вопросов, соответствующих 7 разным сферам: математика и техника, гуманитарная сфера, художественная деятельность, спорт, коммуникативные интересы, природа, домашние обязанности.

Таблица 2.

\begin{tabular}{|c|c|c|c|c|c|c|c|c|}
\hline \multirow[b]{3}{*}{$\begin{array}{c}\text { Количество детей } \\
\text { в семье }\end{array}$} & \multirow[b]{3}{*}{$\begin{array}{c}\text { Уровень } \\
\text { заинтересо- } \\
\text { ванности }\end{array}$} & \multirow{2}{*}{\multicolumn{7}{|c|}{ ресов обучаюш }} \\
\hline & & & & & & & & \\
\hline & & 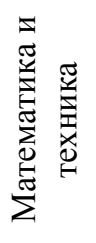 & 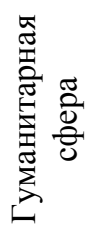 & 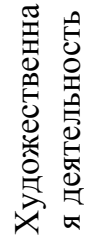 & $\begin{array}{l}\text { 产 } \\
\text { 号 }\end{array}$ &  & 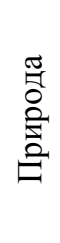 & 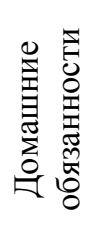 \\
\hline \multirow{5}{*}{$\begin{array}{c}\text { Единственные } \\
\text { дети }\end{array}$} & 5 & 60 & 80 & 60 & 50 & 10 & 80 & 80 \\
\hline & 4 & 10 & 10 & 30 & 40 & 40 & 20 & - \\
\hline & 3 & 20 & 10 & 10 & 10 & 50 & - & 20 \\
\hline & 2 & 10 & - & - & - & - & - & - \\
\hline & 1 & - & - & - & - & - & - & - \\
\hline \multirow{5}{*}{$\begin{array}{c}\text { Дети с } \\
\text { сиблингами }\end{array}$} & 5 & 46 & 85 & 62 & 69 & 8 & 62 & 69 \\
\hline & 4 & 23 & 15 & 31 & 15 & 31 & 23 & 15 \\
\hline & 3 & 15 & - & 8 & 15 & 46 & 8 & - \\
\hline & 2 & 8 & - & - & - & 8 & 8 & 15 \\
\hline & 1 & 8 & - & - & - & 8 & - & - \\
\hline
\end{tabular}

Данные таблицы наглядно можно представить в виде диаграммы (см. рис.1):

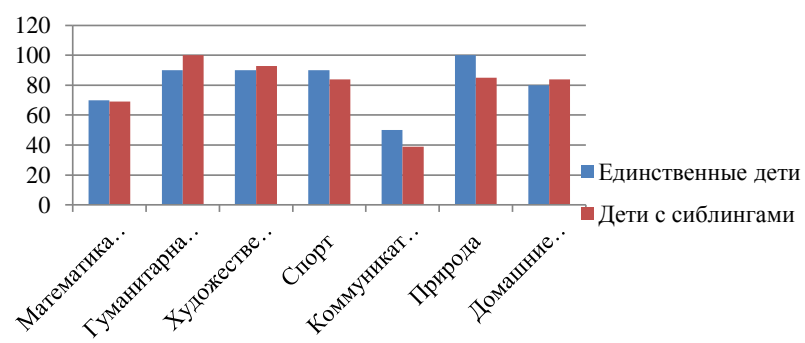

Рисунок 1. Сферы интересов единственных детей и детей с сиблингами

Примечание. В диаграмме представлен суммарный прочент только положительньх данных уровня заинтересованности с показателями 5 и 4 . 
Единственные дети имеют наибольшую склонность к математике и технике, а также интерес к спорту и естествознанию. В художественной деятельности различия между единственными детьми и детьми с братьями или сестрами незначительны (7\%). В обучении дети с сиблингами больше склонны к гуманитарной сфере, в быту имеют более высокую потребность помогать домочадцам и выполнять домашние обязанности (см. рис.1).

Обобщив полученные данные по двум проведенным методикам, мы можем сделать вывод: дети единственные в семье на данном этапе отличаются более высоким уровнем развития коммуникативных способностей, по сравнению с детьми с сиблингами; больше интересуются математикой, техникой, спортом и природой. Однако мы учитываем, что данные имеют некоторую субъективность ситуация может быть обусловлена не только наличием/отсутствием сиблингов, но и гендером или особенностями воспитания (посещение дополнительных кружков, секций).

\section{Литература}

1. Герасимова Е.А. Всероссийская перепись населения / Е.А. Герасимова // Демоскоп Weekly. Электронная версия бюллетеня Население и общество. Институт демографии Государственного университета - Высшей школы экономики. - 2011. - № 491-492. URL: http://demoscope.ru/weekly/2011/0491/perep01.php

2. Гиппенрейтер Ю.Б. Общаться с ребенком. Как? / Ю.Б. Гиппенрейтер. - М.: Мирт, 2007. $-240 \mathrm{c}$.

3. Гитман А. В., Подольная А. М. Особенности социальной адаптации единственного ребенка в семье // Научно-методический электронный журнал «Концепт». - 2016. - Т. 29. - C. 103-110. - URL: http://e-koncept.ru/2016/56560.htm.

4. Давыдов В. В., Слободчиков В.И., Цукерман Г.А. Младший школьник как субъект учебной деятельности / В. В. Давыдов, В.И. Слободчиков, Г.А. Цукерман // Вопросы психологии. - 1992. - №3. - С. 14-19.

5. Национальная энциклопедическая служба России дата обращения. - URL: http://vocabulary.ru/about.html

6. Савенков А.И. Диагностика детской одаренности как педагогическая проблема / А.И. Савенков // Педагогика. - 2000. - № 10. - С. 87-94. 